\title{
喀斯特地区土壤温度变化特征及其与环境因子的关系
}

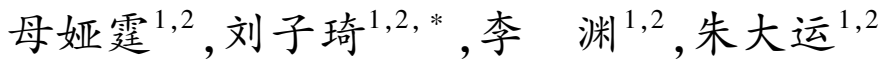 \\ 1 贵州师范大学喀斯特研究院, 贵阳 550001 \\ 2 国家喀斯特石漠化防治工程技术研究中心, 贵阳 550001
}

摘要: 喀斯特地区土壤温度变化特征对研究该区土壤活性及小气候变化具有重要意义。为探明喀斯特地区土壤温度变化特征 及其与环境因子的关系, 以喀斯特高原峡谷区四种典型土地类型 (花椒地、金银花地、火龙果地、荒地) 为研究对象, 采用土壤含 水量监测系统 $(\mathrm{ECH} 2 \mathrm{O})$ 对各样地土壤温度变化进行连续定点监测, 分析土壤温度的动态变化特征及其与环境因子的关系。结 果表明: $10 \mathrm{~cm}$ 处土壤温度日变幅最大, 土层越深日变幅越小; 土壤温度日变幅为夏季较大,秋、冬季较小。火龙果地、金银花地 土壤温度日变幅明显大于花椒地、荒地; 随着土层加深, 土壤温度日变化出现滞后现象; 不同季节土壤温度均为火龙果地 $>$ 荒地 $>$ 花椒地>金银花地。夏季土层越深, 土壤温度越低; 秋、冬季土层越深, 土壤温度越高; 土壤垂直温度变异系数表现为冬季大于 夏季。相关分析表明, 土壤温度与气温、太阳辐射及土壤含水量均呈显著正相关 $(P<0.05)$, 土壤温度变化与容重、孔隙度、土壤 质地、有机碳等土壤理化性质相关性显著。花椒地土壤温度日变幅最小,与其较高的土壤含水量和总孔隙度、容重小、土壤持水 性强密切相关。综上, 花椒地对土壤温度的调节效果较好, 因此, 在喀斯特地区生态恢复的过程中, 种植花椒能在一定程度上改 善土壤性质, 提升土壤肥力。本研究为喀斯特地区的生态恢复提供了科学依据, 为植被生态效益评价提供一定参考。

关键词: 土壤温度;土地类型;环境因子; 喀斯特

\section{Characteristics of soil temperature variation in karst area and its relationship with environmental factors}

\author{
MU Yating ${ }^{1,2}$, LIU Ziqi ${ }^{1,2, *}$, LI Yuan ${ }^{1,2}$, ZHU Dayun ${ }^{1,2}$ \\ 1 School of Karst Science, Guizhou Normal University, Guiyang 550001, China \\ 2 State Engineering Technology Institute for Karst Desertification Control, Guiyang 550001, China
}

\begin{abstract}
Characteristics of soil temperature variation in karst area are of great significance to the study of soil activity and microclimate change. To verify the variation characteristics of soil temperature in karst areas and its relationship with environmental factors, four typical land types including Zanthoxylum bungeanum ( HJ), Hylocereus undulates ( HLG), Lonicera japonica (JYH) and wasteland ( HD) in the Karst plateau canyon were taken as research objects. Soil moisture monitoring system ( ECH2O ) was used for continuous fixed-point monitoring of different sites. The dynamic change characteristics of soil temperature at different time scales and its relationship with environmental factors were analyzed. The results showed that the daily variation of soil temperature was characterized by the sharpest diurnal variation of soil temperature appeared at $10 \mathrm{~cm}$, and the deeper the soil depth, the smaller the diurnal variation. There was a great diurnal variation of soil temperature in summer but a smaller in autumn and winter. The diurnal variation of soil temperature in HL and JYH were significantly greater than that in $\mathrm{HJ}$ and $\mathrm{HD}$ as the soil depth deepens. There was a hysteresis effect in the

基金项目: 贵州省研究生教育创新计划项目 (黔教研合 GZS 字 [2016] 04 号); 国家十三五重点研发计划课题 (2016YFC0502606); 贵州教育厅青 年科技人才成长 (黔教合 KY 字 [2018]127); 贵州省科技支撑计划(黔科合支撑 [2018]2777)

收稿日期: 2019-11-10; 网络出版日期: 2021-01-08

* 通讯作者 Corresponding author.E-mail: 124294329@ qq.com
\end{abstract}


diurnal variation of soil temperature. The daily variation of soil temperature at $10 \mathrm{~cm}$ and $25 \mathrm{~cm}$ of different land types showed a cubic function. The variation of soil temperature in different seasons was as follows: HLG > HD> HJ> JYH. The vertical variation characteristics of soil temperature was that the deeper the soil layer in summer, the lower the soil temperature was. The deeper the soil layer in autumn and winter, the higher the soil temperature. The vertical variation coefficient of soil temperature was greater in winter than in summer. There was significantly positive correlation between soil temperature with atmospheric temperature, solar radiation and soil moisture content $(P<0.05)$. There was also a significantly close correlation between soil temperature variation with soil properties such as soil bulk density, porosity, soil texture, and organic carbon. The diurnal variation of soil temperature in HJ was the smallest, which has a close relationship with the higher soil moisture content and porosity, the better soil water holding capacity and the smaller bulk density. The soil temperature regulation capacity of HJ was the best among the four land types, therefore, the land type of HJ can improve soil properties and soil fertility to a great extent in the process of ecological restoration in karst areas. This study provides a scientific basis for ecological restoration and some reference for ecological benefits evaluation of vegetation in karst areas.

Key Words : soil temperature; land types; environmental factors ; karst

喀斯特地貌在世界上分布广泛, 其演变发展与全球变化和碳循环关系密切 ${ }^{[1-3]}$ 。中国南方喀斯特在全球 三大喀斯特集中连片区域中分布面积最大、发育类型最全 ${ }^{[4]}$ 。西南喀斯特地区生境脆弱, 对气候变化敏感。 土壤温度的动态变化特征对研究喀斯特山区生态交错带的土壤活性及生态小气候的监测具有重要意义, 也有 助于揭示土壤温度对喀斯特山区生态环境和生产力的影响 ${ }^{[5]}$ 。作为影响土壤呼吸速率的重要因子, 土壤温 度对土壤无机碳释放具有重要影响 ${ }^{[6]}$ 。有研究发现, 西南地区年降雨量和降雨次数逐渐下降, 而且极端降水 事件增多, 导致该区碳酸盐集聚层变浅、土壤无机碳库流失巨大 ${ }^{[7-8]}$ 。因此, 在全球气候变化和极端降水事件 增加的背景下, 研究喀斯特地区土壤温度变化特征及其影响因子能够为喀斯特土壤肥力评价提供科学参考, 对于揭示喀斯特地区土壤碳循环和固存机理具有重要意义。

近年来, 地温变化已经引起国内外学者的广泛关注。国内外也开展了诸多关于土壤温度的研究, 主要集 中在不同覆盖方式对土壤水热的影响 ${ }^{[9-10]}$ 、耕作方式及土壤水分对土壤温度的影响 ${ }^{[11-13]}$ 。唐振兴等 ${ }^{[14]}$ 、牛望贷 等 ${ }^{[15-16]}$ 研究了祁连山土壤温度的垂直分层变化特征、空间变化特征及其影响因素。 $\mathrm{Hu}$ 和 $\mathrm{Feng}^{[17]}$ 利用美国 1967-2002 年气象站观测的土壤温度数据, 分析了 0-100 cm 不同深度年均土壤温度的空间分异以及 $10 \mathrm{~cm}$ 深度土壤温度的季节变化。以上研究虽然对土壤温度变化过程有了一定认识,但目前有关喀斯特地区的土壤 温度的研究成果较少, 尤其缺乏土壤温度与气温的同步观测资料。吴克华等 ${ }^{[18]}$ 的研究发现随着石漠化综合 治理时间延长,植被结构得到改善, 小气候效应逐渐凸现: 不同等级石漠化样地林下平均气温及土壤温度在湿 热季节得到有效降低, 而在干冷季节略显升高。张邦琨等 ${ }^{[19]}$ 的研究发现喀斯特地貌上发育的常绿阉叶林的 土壤温度与土壤热通量的变化幅度均为常绿阔叶林 $<$ 马尾松林 $<$ 草地。本研究选择喀斯特高原峡谷区一贞丰 北盘江示范区作为研究区, 通过对研究区内典型土地类型 (花椒地、金银花地、火龙果地、荒地) 的土壤温度、 土壤含水量与当地气温、太阳辐射等环境因子进行定点连续观测, 分析土壤温度的变化特征, 揭示土壤温度在 时间和空间格局上的演变规律, 建立土壤温度与环境因子间的相关关系, 以期在全球变化背景下,为土壤温度 对气候变化的响应机制研究提供参考,进而为喀斯特地区生态系统的恢复与重建提供科学依据。

\section{1 研究区域与方法}

\section{1 研究区概况}

研究区位于贵州省安顺市与黔西南州交界处的花江峡谷两岸, 喀斯特高原峡谷贞丰北盘江石漠化综合治 理示范区内 $\left(25^{\circ} 39^{\prime} 01^{\prime \prime}-25^{\circ} 40^{\prime} 06^{\prime \prime} \mathrm{N}, 105^{\circ} 39^{\prime} 36^{\prime \prime}-105^{\circ} 38^{\prime} 23^{\prime \prime} \mathrm{E}\right)$, 面积约 $51.62 \mathrm{~km}^{2}$, 属于典型的喀斯特高原 
峡谷地貌, 碳酸盐岩广布, 喀斯特地貌极为发育。地形破碎, 地势起伏大, 海拔 450-1450 m, 相对高差为 $1000 \mathrm{~m}$ 。水土流失严重, 基岩裸露率高, 石漠化面积达 $726.63 \mathrm{hm}^{2}$, 中强度石漠化面积占石漠化总面积的 $80.68 \%$ 。气候类型属亚热带干热河谷气候, 光热资源充沛, 冬春温暖干旱, 夏秋较为湿热, 年均气温 $18.4^{\circ} \mathrm{C}$, 年极端最高气温为 $32.4^{\circ} \mathrm{C}, \geqslant 10^{\circ} \mathrm{C}$ 积温 $6542^{\circ} \mathrm{C}$ 。年均降雨量 $1100 \mathrm{~mm}$,降水集中在 $5-8$ 月,约占全年 降雨量的 $83 \%$ 。区内岩石多属三叠系的白云岩、泥质白云岩及页岩。土壤多以黑色、棕黄色石灰土为主, 土 壤质地大多为粘壤土、粘土。植被为亚热带常绿落叶针阔混交林, 原生植被基本上已被破坏, 现以次生植被为 主。花椒 (Zanthoxylum bungeanum Maxim) 、金银花 (Lonicera japonica Thunb)、火龙果 (Hylocereus undatus 'Foo$\left.L o n^{\prime}\right)$ 为该区主要石漠化生态恢复植被,种植面积广, 取得了良好的生态经济效益。

\section{2 实验设计}

在研究区内设立小型气象站 (ATMOS, Meter 公司, 美国), 间隔 $10 \mathrm{~min}$ 实时记录大气温度、降雨量、太阳辐 射等数据。选择该区海拔、坡度相近, 且距离接近气候一致, 具有代表性的 4 种典型土地类型( 花椒地、金银 花地、火龙果地和荒地) 的土地作为研究对象。分别在 4 种土地类型距离植株 $30 \mathrm{~cm}$ 处, 自地表向下于 10 、 $25 、 40 、 55 \mathrm{~cm}$ 土层安装土壤水分温度电导率传感器 ( $5 \mathrm{TE}$, Meter 公司, 美国), 数据采集器 ( EM50, Meter 公司, 美国) 每间隔 $10 \mathrm{~min}$ 采集土壤温度、土壤含水量数据。完整的监测时间为 2018 年 5 月 1 日至 2019 年 3 月 31 日。安装传感器同时采集土壤样品, 在监测点距植株 30-50 cm 处另开挖 2 个土壤剖面, 共 3 个土壤剖面, 分 别在传感器埋设深度上下 $5 \mathrm{~cm}$ 范围内采环刀和扰动土。扰动土自封袋密封带回实验室阴凉风干, 再去除根 系等杂物, 并将土样分成两份,一份用玛瑙钵研磨过 100 目篮后用于测定有机碳, 另一份用于测定土壤颗粒组 成。土壤有机碳的测定采用重铬酸钾加热法, 土壤容重、孔隙度采用环刀法测定, 土壤颗粒组成采用比重计法 测定。样地基本概况见表 1 。

\section{表 1 样地基本概况}

Table 1 Status of the sampling sites

\begin{tabular}{|c|c|c|c|c|}
\hline 项目 Items & $\begin{array}{c}\text { 花椒地 } \\
\text { Pepper land }\end{array}$ & $\begin{array}{c}\text { 金银花地 } \\
\text { Honeysuckle land }\end{array}$ & $\begin{array}{c}\text { 火龙果地 } \\
\text { Dragon fruit land }\end{array}$ & $\begin{array}{c}\text { 荒地 } \\
\text { Wasteland }\end{array}$ \\
\hline 坐标 Coordinates & $25^{\circ} 39^{\prime} 40^{\prime \prime} \mathrm{N} \quad 105^{\circ} 38^{\prime} 50^{\prime \prime} \mathrm{E}$ & $25^{\circ} 39^{\prime} 01^{\prime \prime} \mathrm{N} \quad 105^{\circ} 38^{\prime} 23^{\prime \prime} \mathrm{E}$ & $25^{\circ} 40^{\prime} 25^{\prime \prime} \mathrm{N} \quad 105^{\circ} 39^{\prime} 61^{\prime \prime} \mathrm{E}$ & $25^{\circ} 39^{\prime} 36^{\prime \prime} \mathrm{N} \quad 105^{\circ} 38^{\prime} 42^{\prime \prime} \mathrm{E}$ \\
\hline 海拔 Altitude/m & 713 & 716 & 705 & 731 \\
\hline 盖度 Coverage/\% & 70 & 85 & 45 & 65 \\
\hline 坡度 Gradient $/\left(^{\circ}\right)$ & 18 & 25 & 15 & 12 \\
\hline 坡向 Aspect $/\left(^{\circ}\right)$ & 10 & 25 & 242 & 131 \\
\hline 土壤质地 Texture & 粘壤土、粘土 & 粘壤土、粘土 & 粘壤土、粘土 & 粘壤土、粘土 \\
\hline
\end{tabular}

\section{3 数据处理分析}

使用 Excel 2013 软件对数据进行统计分析, 采用 SPSS 18.0 软件进行土壤温度与气温、太阳辐射、土壤含 水量及土壤理化性质等环境因子的 Pearson 相关分析,采用 Origin 9.0 软件绘图。

\section{2 结果分析}

\section{1 土壤温度的时间变化特征}

土壤温度日变化是一天内土壤热状况的直接反映。由图 1 可以看出,一天内土壤温度的波动幅度表现为 $10 \mathrm{~cm}$ 处最大, 土层越深, 波动越小。各地类 $10 \mathrm{~cm}$ 处土壤温度均呈近似单峰变化。一天内土壤温度最小值 的出现时刻分别为花椒地 8:00、金银花地 8:00、火龙果地 9:00、荒地 9:00, 最低温分别为 19.9、18.2、21.6、 $20.4^{\circ} \mathrm{C}$; 土壤温度最大值的出现时刻分别为花椒地 $17: 30$ 、金银花地 $16: 30$ 、火龙果地 $18: 30$ 、荒地 $18: 00$, 最高 温分别为 $21.4 、 20.3 、 24.0 、 21.9^{\circ} \mathrm{C}$, 土壤温度最值的出现随着土层加深出现滞后效应。一天内土壤温度最值均 为火龙果地 $>$ 荒地 $>$ 花椒地 $>$ 金银花地。 $10 \mathrm{~cm}$ 处土壤温度日变幅分别为花椒地 $1.5^{\circ} \mathrm{C}$ 、金银花地 $2.1^{\circ} \mathrm{C}$ 、火龙果 
地 $2.4^{\circ} \mathrm{C}$ 、荒地 $1.5^{\circ} \mathrm{C}$, 火龙果地、金银花地土壤温度日变幅明显大于花椒地、荒地, 表明火龙果地、金银花地土 壤温度的昼夜变化较大,而花椒地与荒地一天内土壤温度较为稳定。

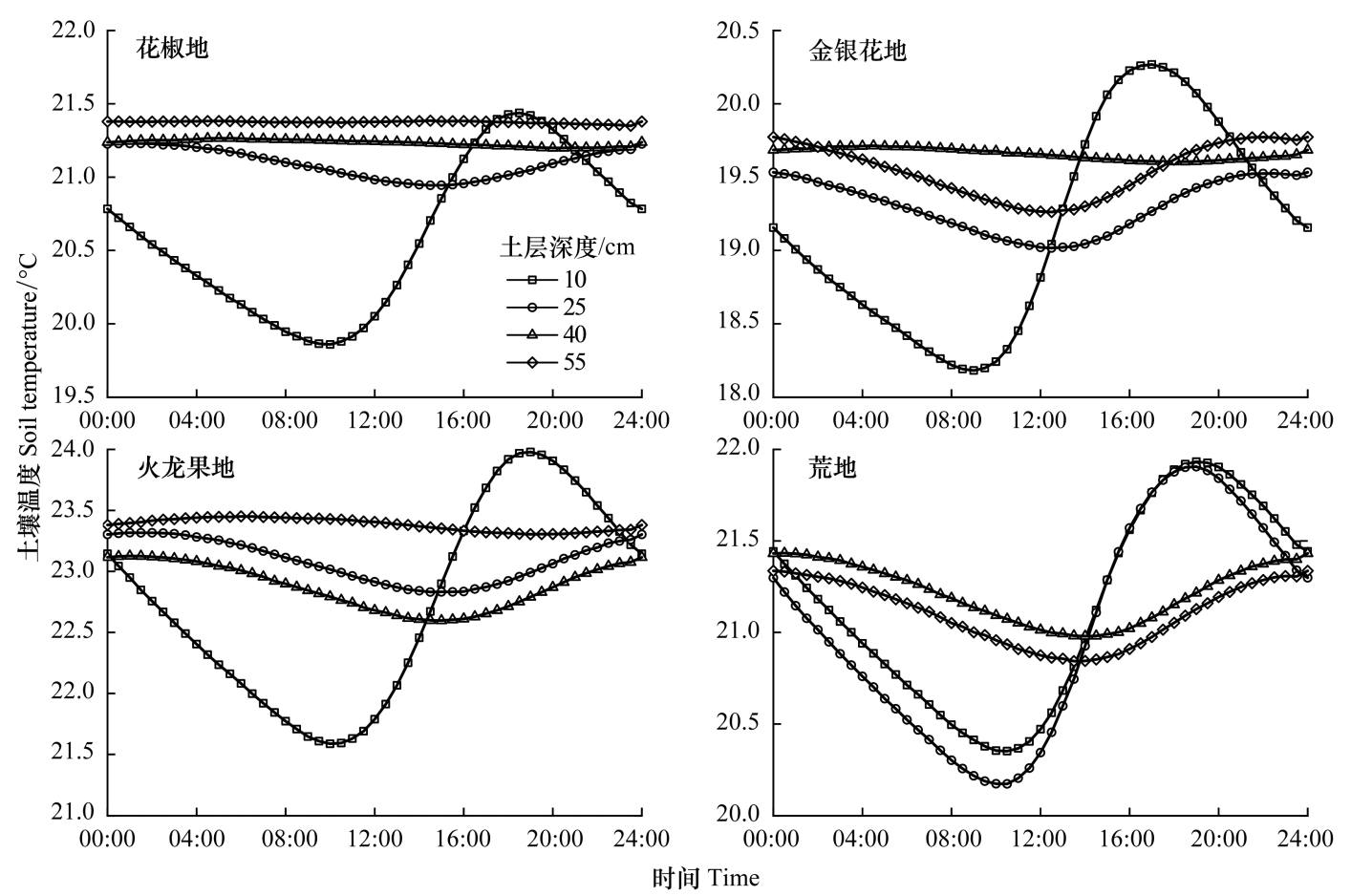

图 1 土壤温度的日变化特征曲线

Fig.1 Diurnal variation characteristic curves of soil temperature

由于浅层土壤温度一天内波动较大, 较深层土壤温度波动较小, 因此, 用 $0: 00-24: 00$ 温度值拟合处理 1 月和 7 月 $10 \mathrm{~cm} 、 25 \mathrm{~cm}$ 处土壤温度日变化特征曲线,不同深度土壤温度日变化均呈三次函数 $(y$ 为土壤温 度, $x$ 为时间), 回归决定系数均在 0.8 以上, 表明土壤温度与时间 $(0: 00-24: 00)$ 有较强显著性 $(P<0.05)$ 。荒 地 $10 \mathrm{~cm}$ 与 $25 \mathrm{~cm}$ 日最高温在 7 月同时出现, 1 月则表现为 $25 \mathrm{~cm}$ 滞后于 $10 \mathrm{~cm}$ 。其他地类日最高温的出现均 为 $25 \mathrm{~cm}$ 滞后于 $10 \mathrm{~cm}$, 且火龙果地与金银花地的滞后时间大于花椒地与荒地。花椒地、火龙果地、金银花地 土壤温度最大值在 7 月表现为 $10 \mathrm{~cm}$ 明显大于 $25 \mathrm{~cm}$,荒地表现为 $10 \mathrm{~cm}$ 和 $25 \mathrm{~cm}$ 差异不大; 各地类 $10 \mathrm{~cm}$ 与 $25 \mathrm{~cm}$ 处土壤温度最大值在 1 月无明显差异 (表 2)。

由于土壤温度日变化表现为 $10 \mathrm{~cm}$ 处日变幅最大, 较深层土壤日变幅较小。因此,进一步分析不同季节 $10 \mathrm{~cm}$ 处土壤温度的日变化特征。不同季节土壤温度呈相似的变化趋势, 均呈单峰变化 (图 2)。夏季一天中 土壤温度最大值分别为花椒地 $27.4^{\circ} \mathrm{C}$ 、金银花地 $27.6^{\circ} \mathrm{C}$ 、火龙果地 $31.2^{\circ} \mathrm{C}$ 、荒地 $28.1^{\circ} \mathrm{C}$; 秋季分别为花椒地 $21.9^{\circ} \mathrm{C}$ 、金银花地 $20.4^{\circ} \mathrm{C}$ 、火龙果地 $24.3^{\circ} \mathrm{C}$ 、荒地 $22.6^{\circ} \mathrm{C}$; 冬季分别为花椒地 $15.0^{\circ} \mathrm{C}$ 、金银花地 $12.8^{\circ} \mathrm{C}$ 、火龙果 地 $16.4^{\circ} \mathrm{C}$ 、荒地 $15.1^{\circ} \mathrm{C}$; 夏、秋、冬季 $10 \mathrm{~cm}$ 处土壤温度均为火龙果地>荒地 >花椒地>金银花地。10 $\mathrm{cm}$ 处土壤 温度日变幅在夏季和秋季均为火龙果地 $>$ 金银花地 $>$ 荒地 $>$ 花椒地, 冬季为火龙果地 $>$ 花椒地 $>$ 金银花地 $>$ 荒 地, 不同季节均为火龙果地的日变幅最大, 且 4 种地类土壤温度日变幅均在夏季出现最大值 (表 3 )。

\section{2 土壤温度剖面的变化特征}

土壤温度不仅受太阳辐射、下垫面、土壤性质等因素的影响表现出季节差异。而且在垂直方向上也具有 一定的变化规律。夏季土壤温度随土层加深而减小; 秋、冬季随土层加深而增大(图 3)。由表 4 可以看出, 不 同季节土壤垂直温度变异系数存在差异, 夏季分别为花椒地 $1.1 \%$ 、荒地 $1.0 \%$ 、火龙果地 $1.4 \%$ 、金银花地 
$2.0 \%$, 不同土地类型土壤垂直温度变异系数差异很小; 秋季分别为花椒地 $2.6 \%$ 、荒地 $0.8 \%$ 、炏龙果地 $2.3 \%$ 、 金银花地 $2.3 \%$, 冬季分别为花椒地 $4.6 \%$ 、荒地 $1.8 \%$ 、火龙果地 $4.0 \%$ 、金银花地 $5.2 \%$,秋、冬季土壤垂直温度 变异系数表现为花椒地、火龙果地、金银花地明显大于荒地, 说明荒地土壤导热性能较好。四种地类土壤垂直 温度变异系数均为冬季较大,夏季较小。

表 2 不同深度土壤温度日变幅特征

Table 2 Diurnal variation of soil temperature at different depths

\begin{tabular}{|c|c|c|c|c|c|c|}
\hline $\begin{array}{l}\text { 土地类型 } \\
\text { Land types }\end{array}$ & $\begin{array}{l}\text { 月份 } \\
\text { Month }\end{array}$ & $\begin{array}{c}\text { 深度 } \\
\text { Depth/cm }\end{array}$ & $\begin{array}{c}\text { 最高温度 } \\
\text { Maximum } \\
\text { temperature } /{ }^{\circ} \mathrm{C}\end{array}$ & $\begin{array}{l}\text { 时刻 } \\
\text { Time }\end{array}$ & $\begin{array}{l}\text { 拟合函数 } \\
\text { Fitting function }\end{array}$ & $\begin{array}{c}\text { 相关系数 } \\
\text { Correlation } \\
\text { coefficient } / R^{2}\end{array}$ \\
\hline \multirow[t]{4}{*}{ 花椒地 } & 7 & 10 & 36.9 & $17: 00$ & $y=-8.132 x^{3}+10.394 x^{2}-2.15 x+25.678$ & 0.860 \\
\hline & & 25 & 27.4 & $18: 00$ & $y=-8.030 x^{3}+14.467 x^{2}-5.977 x+27.251$ & 0.883 \\
\hline & 1 & 10 & 13.7 & $18: 30$ & $y=-6.971 x^{3}+12.821 x^{2}-5.343 x+13.455$ & 0.836 \\
\hline & & 25 & 13.8 & $20: 30$ & $y=8.380 x^{3}-10.017 x^{2}+1.963 x+13.728$ & 0.948 \\
\hline \multirow[t]{4}{*}{ 荒地 } & 7 & 10 & 29.4 & $17: 30$ & $y=-8.547 x^{3}+15.097 x^{2}-6.122 x+29.304$ & 0.869 \\
\hline & & 25 & 29.5 & $17: 30$ & $y=-8.967 x^{3}+15.463 x^{2}-6.074 x+29.281$ & 0.872 \\
\hline & 1 & 10 & 13.5 & $18: 30$ & $y=-3.898 x^{3}+8.858 x^{2}-4.409 x+13.383$ & 0.834 \\
\hline & & 25 & 13.4 & $19: 00$ & $y=-4.702 x^{3}+9.948 x^{2}-4.703 x+13.280$ & 0.833 \\
\hline \multirow[t]{4}{*}{ 火龙果地 } & 7 & 10 & 33.4 & $19: 00$ & $y=-7.570 x^{3}+13.954 x^{2}-5.913 x+33.173$ & 0.887 \\
\hline & & 25 & 30.8 & $23: 30$ & $y=6.117 x^{3}-6.339 x^{2}+0.194 x+30.760$ & 0.951 \\
\hline & 1 & 10 & 14.5 & $18: 30$ & $y=-5.743 x^{3}+11.272 x^{2}-4.995 x+14.307$ & 0.833 \\
\hline & & 25 & 14.8 & $23: 30$ & $y=7.979 x^{3}-9.299 x^{2}+1.642 x+14.626$ & 0.952 \\
\hline \multirow[t]{4}{*}{ 金银花地 } & 7 & 10 & 29.2 & $16: 30$ & $y=-9.714 x^{3}+15.967 x^{2}-2015 x+25.678$ & 0.897 \\
\hline & & 25 & 26.9 & $22: 00$ & $y=0.256 x^{3}+3.398 x^{2}-3.379 x+26.997$ & 0.884 \\
\hline & 1 & 10 & 11.8 & $17: 00$ & $y=-8.364 x^{3}+14.175 x^{2}-5.327 x+11.440$ & 0.863 \\
\hline & & 25 & 11.8 & $21: 30$ & $y=1.965 x^{3}+0.310 x^{2}-1.678 x+11.661$ & 0.901 \\
\hline
\end{tabular}
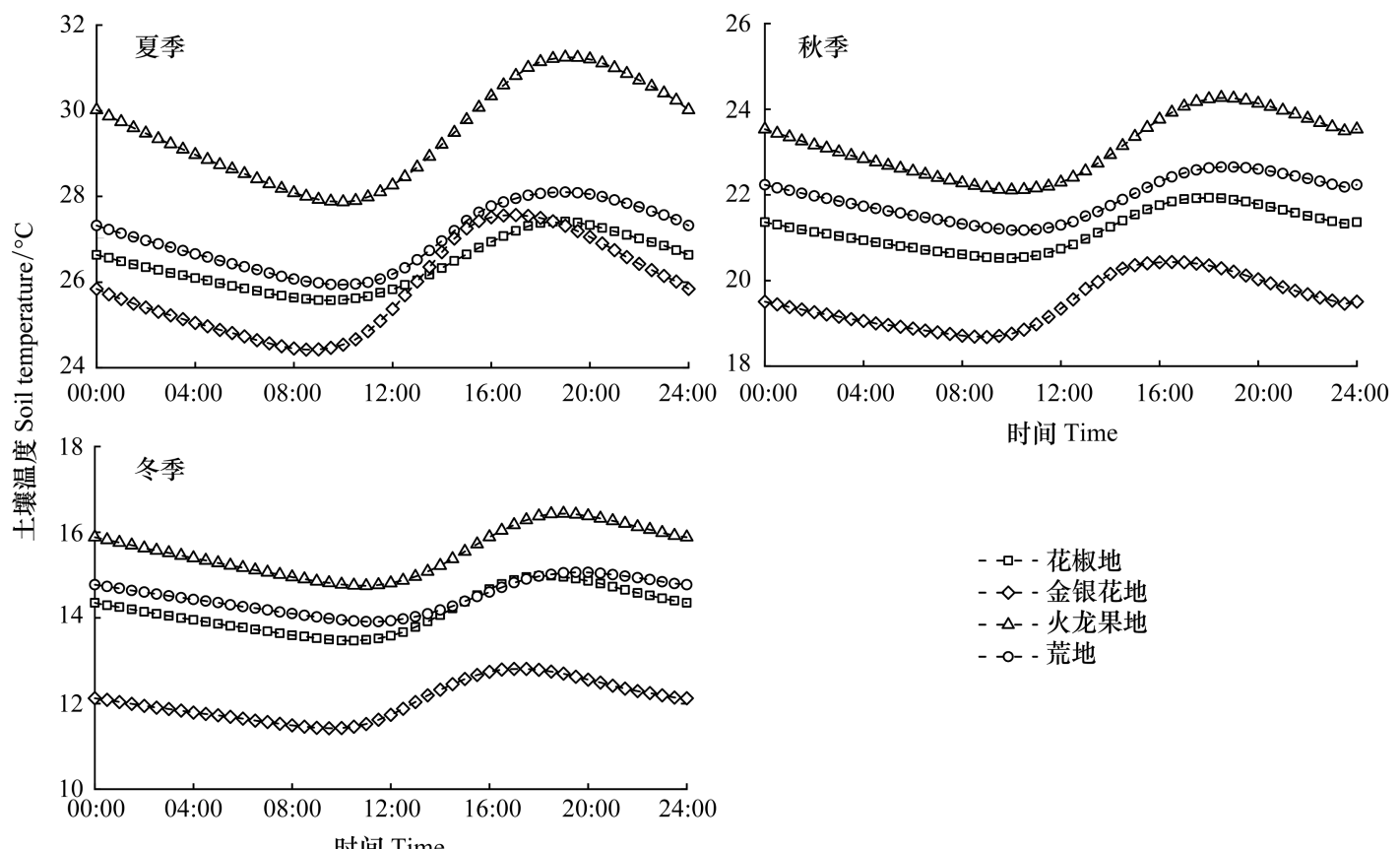

时间 Time

图 2 不同季节 $10 \mathrm{~cm}$ 土壤温度的日变化特征曲线

Fig.2 Diurnal variation characteristic curves of soil temperature at $10 \mathrm{~cm}$ in different seasons 
表 3 不同季节 $10 \mathrm{~cm}$ 土壤温度日变化特征

Table 3 Diurnal variation of soil temperature at $10 \mathrm{~cm}$ in different Seasons

\begin{tabular}{|c|c|c|c|c|c|}
\hline $\begin{array}{l}\text { 土地类型 } \\
\text { Land types }\end{array}$ & $\begin{array}{l}\text { 季节 } \\
\text { Season }\end{array}$ & $\begin{array}{c}\text { 日最高温 } \\
\text { Daily maximum } \\
\text { temperature } /{ }^{\circ} \mathrm{C}\end{array}$ & $\begin{array}{c}\text { 日最低温 } \\
\text { Daily minimum } \\
\text { temperature } /{ }^{\circ} \mathrm{C}\end{array}$ & $\begin{array}{c}\text { 日变幅 } \\
\text { Daily amplitude } /{ }^{\circ} \mathrm{C}\end{array}$ & $\begin{array}{c}\text { 日均温 } \\
\text { Daily mean } \\
\text { temperature } /{ }^{\circ} \mathrm{C}\end{array}$ \\
\hline \multirow[t]{3}{*}{ 花椒地 } & 夏 & 27.4 & 25.6 & 1.8 & 26.4 \\
\hline & 秋 & 21.9 & 20.5 & 1.4 & 21.2 \\
\hline & 冬 & 15.0 & 13.5 & 1.5 & 14.2 \\
\hline \multirow[t]{3}{*}{ 荒地 } & 夏 & 28.1 & 25.9 & 2.2 & 27.0 \\
\hline & 秋 & 22.6 & 21.2 & 1.4 & 21.9 \\
\hline & 冬 & 15.1 & 13.9 & 1.2 & 14.5 \\
\hline \multirow[t]{3}{*}{ 火龙果地 } & 夏 & 31.2 & 27.9 & 3.3 & 29.5 \\
\hline & 秋 & 24.3 & 22.1 & 2.2 & 23.1 \\
\hline & 冬 & 16.4 & 14.7 & 1.7 & 15.5 \\
\hline \multirow[t]{3}{*}{ 金银花地 } & 夏 & 27.6 & 24.4 & 3.2 & 25.9 \\
\hline & 秋 & 20.4 & 18.7 & 1.7 & 19.5 \\
\hline & 冬 & 12.8 & 11.4 & 1.4 & 12.1 \\
\hline
\end{tabular}

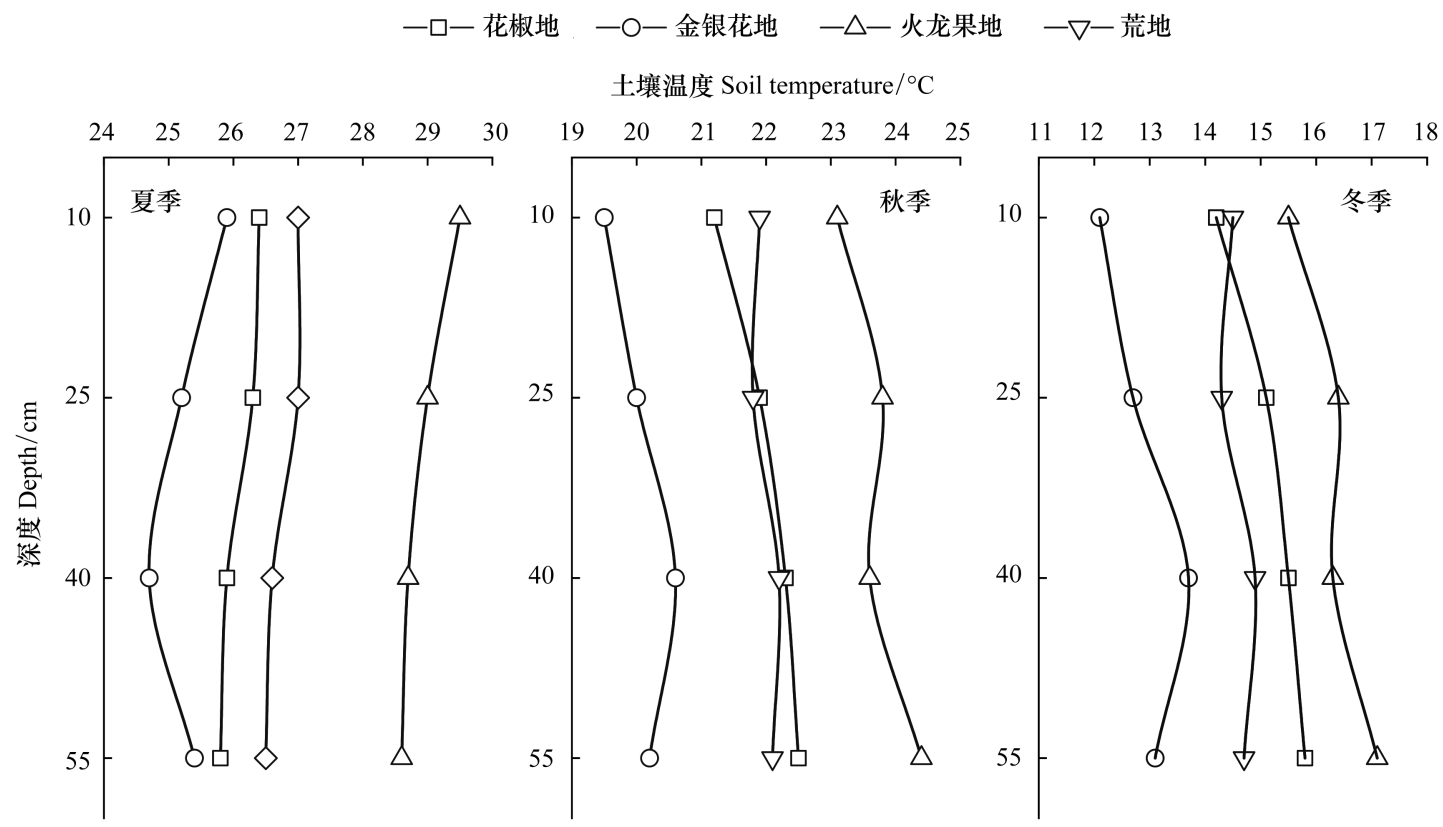

图 3 不同季节土壤温度的垂直变化特征

Fig.3 Vertical variation characteristics of soil temperature in different seasons

表 4 不同季节土壤垂直温度变异系数

Table 4 Coefficient of temperature variation of soil profile in different seasons

\begin{tabular}{lcccc}
\hline 季节 Season & 花椒地/\% & 荒地/\% & 火龙果地/\% & 金银花地/\% \\
\hline 夏季 Summer & 1.1 & 1.0 & 1.4 & 2.0 \\
秋季 Autumn & 2.6 & 0.8 & 2.3 & 2.3 \\
冬季 Winter & 4.6 & 1.8 & 4.0 & 5.2 \\
\hline
\end{tabular}

2.3 环境因子对土壤温度的影响

2.3.1 土壤理化性质对土壤温度变化的影响

由图 4 可以看出, 各样地表现为随着土层加深, 土壤容重、粘粒含量整体上呈逐渐增大的趋势, 土壤总孔 
隙度、有机碳含量及砂粒含量则呈逐渐减小的趋势, 土壤毛管孔隙度随着土层加深先减小后增大, 而土壤非毛 管孔隙度和粉粒含量表现为先增大后减小。不同土层土壤容重、粘粒含量均为火龙果地 $>$ 金银花地 $>$ 荒地 $>$ 花 椒地; 土壤总孔隙度、砂粒含量及有机碳含量均为花椒地 $>$ 荒地 $>$ 金银花地 $>$ 火龙果地; 浅层土壤粉粒含量为火 龙果地>花椒地>荒地>金银花地, 较深层土壤粉粒含量为金银花地>荒地>花椒地>火龙果地。

土壤温度变化与土壤理化性质密切相关。相关分析表明,土壤温度日变幅与土壤有机碳、砂粒含量和非 毛管孔隙度均呈极显著正相关 $(P<0.01)$, 与粉粒含量、容重呈显著负相关 $(P<0.05)$, 与粘粒含量、总孔隙度、 毛管孔隙度相关性不显著( 表 5)。由此可见,土壤温度日变幅受土壤通气条件和质地等因素影响。有机碳、 砂粒含量越高, 土壤导热率越高; 非毛管孔隙度越大,越有利于土壤与大气之间的能量交换, 土壤温度的日变 化幅度也就越大。

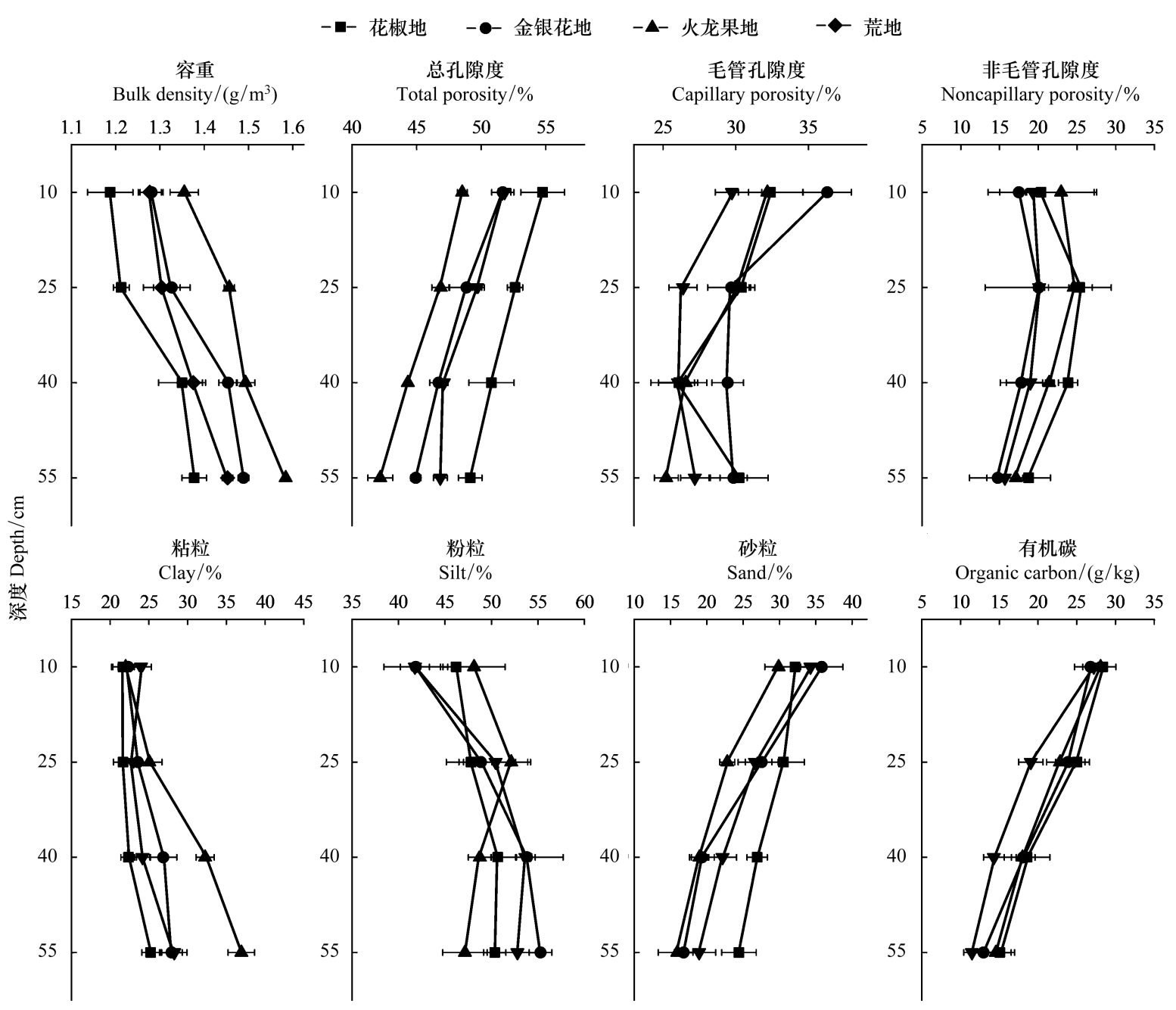

图 4 各样地土壤基本理化性质

Fig.4 Basic soil properties of sampling sites

\subsection{2 气温、太阳辐射、土壤含水量对土壤温度的影响}

土壤温度变化是土壤随着太阳辐射和大气温度的变化而吸收或释放能量的过程 ${ }^{[21]}$ 。由图 5 可以看出, 土壤温度与太阳辐射和气温的变化趋势大致相同。2018 年 5 月至 2019 年 3 月,最高气温出现在 7 月, 为 $31.0^{\circ} \mathrm{C}$, 最大太阳辐射也出现在 7 月, 为 $428.12 \mu \mathrm{mol} \mathrm{m}^{-2} \mathrm{~s}^{-1}$ 。花椒地和金银花地 $10 、 25 \mathrm{~cm}$ 处土壤温度最大值 出现在 7 月, $40 \mathrm{~cm} 、 55 \mathrm{~cm}$ 处土壤温度最大值出现在 8 月,较气温和太阳辐射滞后一个月; 荒地各深度土壤温 
度最大值均发生在 7 月, 与气温和太阳辐射同步; 火龙果地各深度土壤温度最大值均发生在 8 月, 较气温与太 阳辐射滞后一个月。土壤温度最大值分别为花椒地 $27.3^{\circ} \mathrm{C}$ 、金银花地 $27.3^{\circ} \mathrm{C}$ 、火龙果地 $30^{\circ} \mathrm{C}$ 、荒地 $28.2^{\circ} \mathrm{C}$ 。 气温最小值出现在 1 月,为 $12.2^{\circ} \mathrm{C}$,太阳辐射最小值也发生在 1 月, 为 $101.96 \mu \mathrm{mol} \mathrm{m}^{-2} \mathrm{~s}^{-1}$, 四种地类土壤温度 最小值均发生在 1 月, 土壤温度最小值分别为花椒地 $12.2^{\circ} \mathrm{C}$ 、金银花地 $11.2^{\circ} \mathrm{C}$ 、火龙果地 $13.8^{\circ} \mathrm{C}$ 、荒地 $13.0^{\circ} \mathrm{C}$ 。 气温与太阳辐射的变化具有同步性,土壤温度最值的出现较气温与太阳辐射存在滞后性,随着土层加深,滞后 越明显。观测期内不同深度土壤温度变幅较大, $10 \mathrm{~cm}$ 处土壤温度变异系数分别为花椒地 $26.39 \%$ 、荒地 $26.51 \%$ 、火龙果地 $26.38 \%$ 、金银花地 $31.70 \%$, 土壤温度变异系数随着土层加深而减小。土壤温度与气温和太 阳辐射均呈显著性正相关 $(P<0.01)$, 且气温与土壤温度的相关性更显著, 相关系数为 $0.959-0.994$ ( 表 6), 说 明气温在土壤温度变化中起重要作用。

表 5 土壤温度与土壤理化性质之间的 Pearson 相关系数

Table 5 Pearson correlation coefficients between soil temperature and soil properties

\begin{tabular}{|c|c|c|c|c|c|c|c|c|c|}
\hline 项目 Items & $X_{1}$ & $X_{2}$ & $X_{3}$ & $X_{4}$ & $X_{5}$ & $X_{6}$ & $X_{7}$ & $X_{8}$ & $Y$ \\
\hline$X_{1}$ & 1 & & & & & & & & \\
\hline$X_{2}$ & $0.860^{* *}$ & 1 & & & & & & & \\
\hline$X_{3}$ & $-0.715^{* *}$ & $-0.748^{* *}$ & 1 & & & & & & \\
\hline$X_{4}$ & -0.612 * & $-0.789^{* * *}$ & 0.182 & 1 & & & & & \\
\hline$X_{5}$ & $-0.715^{* *}$ & $-0.898^{* *}$ & $0.503^{*}$ & $0.864^{* * *}$ & 1 & & & & \\
\hline$X_{6}$ & $0.700^{* *}$ & $0.895^{* * *}$ & $-0.509^{*}$ & $-0.855^{* *}$ & $-0.969^{* *}$ & 1 & & & \\
\hline$X_{7}$ & -0.389 & -0.153 & 0.292 & -0.043 & -0.040 & 0.152 & 1 & & \\
\hline$X_{8}$ & $0.847^{* *}$ & $0.833^{* *}$ & $-0.622^{*}$ & $-0.658^{* *}$ & $-0.752^{* *}$ & $0.696^{* *}$ & $-0.604^{*}$ & 1 & \\
\hline$Y$ & $0.668^{* * *}$ & $0.666^{* *}$ & $-0.576^{*}$ & -0.454 & $-0.497^{*}$ & 0.446 & -0.486 & $0.713^{* *}$ & 1 \\
\hline
\end{tabular}

$X_{1}$ : 有机碳 Organic carbon; $X_{2}$ : 砂粒 Sand; $X_{3}$ : 粉粒 Silt; $X_{4}$ : 粘粒 Clay; $X_{5}$ : 容重 Bulk density; $X_{6}$ : 总孔隙度 Total porosity; $X_{7}$ : 毛管孔隙度 Capillary porosity; $X_{8}$ : 非毛管孔隙度 Noncapillary porosity; $Y$ : 土壤温度日变幅 Diurnal variation of soil temperature; $*$ 和 $* *$ 分别表示在 $P<0.05$ 和 $P<0.01$ 水平上显著相关

表 6 土壤温度与气温、太阳辐射、土壤含水量之间的 Pearson 相关系数

Table 6 Pearson correlation coefficients between soil temperature and air temperature, solar radiation and soil moisture content

\begin{tabular}{|c|c|c|c|c|}
\hline $\begin{array}{l}\text { 土地类型 } \\
\text { Land types }\end{array}$ & $\begin{array}{c}\text { 土层深度 } \\
\text { Soil depth/cm }\end{array}$ & $\begin{array}{c}\text { 气温 } \\
\text { Air temperature }\end{array}$ & $\begin{array}{c}\text { 太阳辐射 } \\
\text { Solar radiation }\end{array}$ & $\begin{array}{c}\text { 土壤含水量 } \\
\text { Soil moisture content }\end{array}$ \\
\hline \multirow[t]{4}{*}{ 花椒地 } & 10 & $0.991^{* *}$ & $0.915^{* *}$ & $0.851^{* *}$ \\
\hline & 25 & $0.983^{* *}$ & $0.891^{* *}$ & $0.717^{*}$ \\
\hline & 40 & 0.970 ** & $0.866^{* *}$ & $0.683^{*}$ \\
\hline & 55 & $0.959^{* *}$ & $0.847^{* *}$ & $0.710^{*}$ \\
\hline \multirow[t]{4}{*}{ 荒地 } & 10 & $0.990^{* *}$ & $0.914^{* *}$ & $0.815^{* *}$ \\
\hline & 25 & $0.991^{* *}$ & $0.916^{* *}$ & $0.727^{*}$ \\
\hline & 40 & $0.979^{* *}$ & $0.889^{* *}$ & $0.792^{* *}$ \\
\hline & 55 & $0.980^{* *}$ & $0.892^{* *}$ & $0.693^{*}$ \\
\hline \multirow[t]{4}{*}{ 火龙果地 } & 10 & $0.994^{* *}$ & $0.934^{* *}$ & $0.817^{* *}$ \\
\hline & 25 & $0.983^{* *}$ & $0.903^{* *}$ & $0.780^{* *}$ \\
\hline & 40 & $0.983^{* *}$ & $0.904^{* *}$ & $0.775^{* *}$ \\
\hline & 55 & $0.980^{* *}$ & $0.876^{* *}$ & $0.659^{*}$ \\
\hline \multirow[t]{4}{*}{ 金银花地 } & 10 & 0.990 ** & $0.921^{* *}$ & $0.839^{* *}$ \\
\hline & 25 & $0.980 * *$ & $0.896^{* *}$ & $0.842^{* *}$ \\
\hline & 40 & $0.960 * *$ & $0.858^{* *}$ & $0.642^{*}$ \\
\hline & 55 & $0.980^{* *}$ & $0.896^{* *}$ & $0.860^{* *}$ \\
\hline
\end{tabular}

$* * P<0.01, * P<0.05$ 

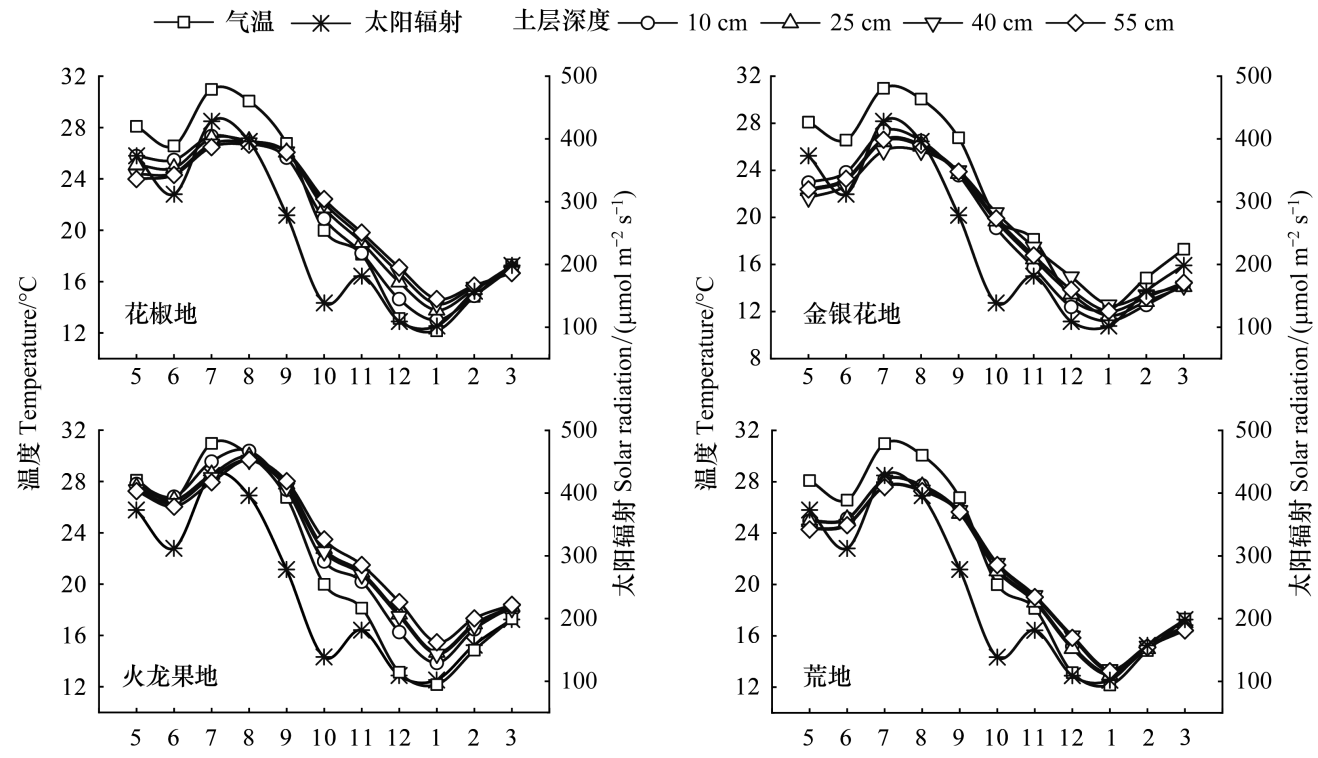

月份 Month
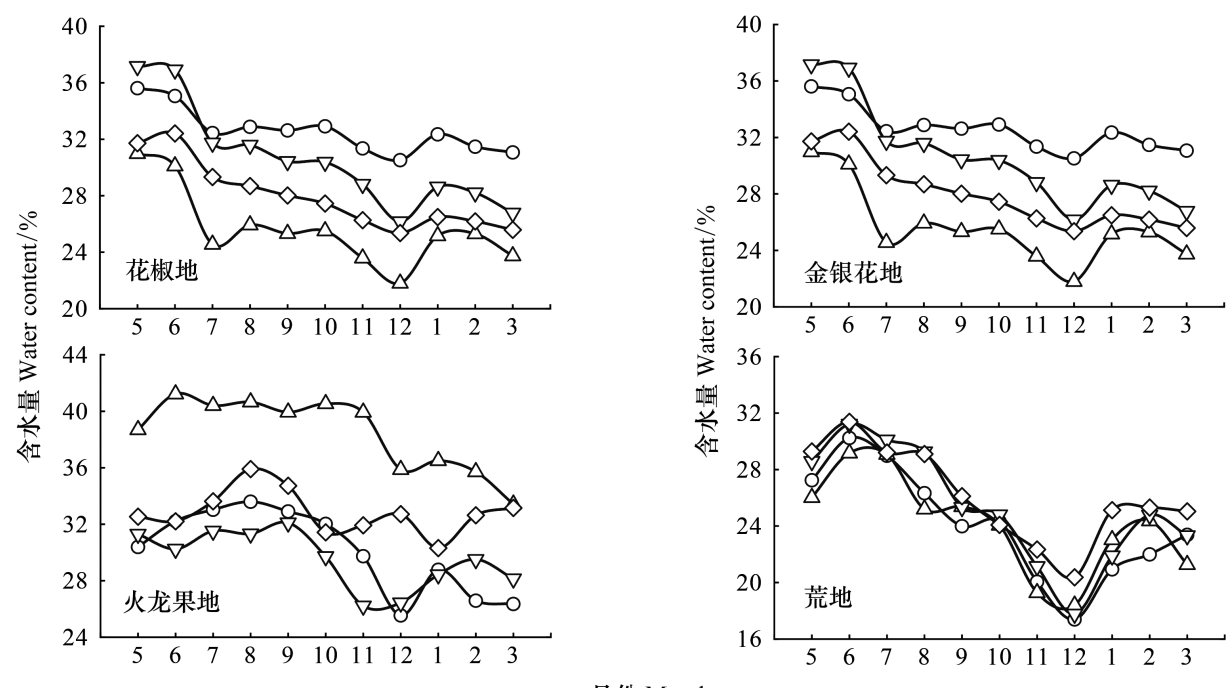

月份 Month

图 5 土壤温度、气温、太阳辐射及土壤含水量的月变化特征曲线

Fig.5 Monthly characteristic curves of soil temperature, air temperature, solar radiation and soil moisture content

观测期内花椒地各土层土壤含水量的波动很小,其他 3 种地类土壤含水量的波动较大(图 5 )。不同深度 土壤含水量的变化趋势大致相同,花椒地、荒地、火龙果地土壤含水量均在 6 月出现最大值,金银花地土壤含 水量在 8 月达到最大值, 不同地类土壤含水量均在 12 月出现最小值。对土壤温度和土壤含水量进行相关分 析 (表 6), 土壤含水量与土壤温度呈显著正相关 $(P<0.05)$, 相关系数为 $0.642-0.860$ 。花椒地 $10 \mathrm{~cm}$ 处土壤 温度与土壤含水量呈极显著正相关 $(P<0.01), 25 、 40 \mathrm{~cm}$ 和 $55 \mathrm{~cm}$ 处呈显著正相关 $(P<0.05)$; 荒地 $10 、 40 \mathrm{~cm}$ 处土壤温度与土壤含水量呈极显著正相关 $(P<0.01), 25 \mathrm{~cm}$ 和 $55 \mathrm{~cm}$ 土层呈显著正相关 $(P<0.05)$; 火龙果地 除 $55 \mathrm{~cm}$ 处土壤温度与土壤含水量呈显著正相关外 $(P<0.05)$, 其他土层均呈极显著正相关 $(P<0.01)$; 金银花 地除 $40 \mathrm{~cm}$ 处土壤温度与土壤含水量呈显著正相关外 $(P<0.05)$, 其他土层均呈极显著正相关 $(P<0.01)$ 。

\section{3 讨论}

3.1 土壤温度的变化特征

观测期内土壤温度日变幅为 $10 \mathrm{~cm}$ 处明显大于较深层土壤, 土层越深, 土壤温度的波动越小。四种地类 
土壤温度的日变化随土层加深均出现滞后现象, 与孙贯芳等 ${ }^{[22]}$ 的研究结果一致。这主要是因为太阳辐射是 控制地表温度的能量来源, 土壤具有巨大的热容性以及传导阻力, 导致地表温度向下传导速度缓慢, 随土层加 深, 土壤温度到达一天中的最大值就滞后。10 $\mathrm{cm}$ 处土壤温度日变幅最大, 这主要是因为土壤温度主要受气 温的影响, 气温对表层土壤的影响最大, 且土壤对太阳辐射有显著削弱作用 ${ }^{[23]}$, 因此土层越深, 土壤接收的太 阳辐射量就越少, 土壤温度受气温的影响也越小, 因而, 土壤温度的变幅就越小。在 $8: 00$ 以前, 气温很低, 受 气温影响 $10 \mathrm{~cm}$ 土壤温度低于深层土壤, $8: 00$ 以后气温开始迅速上升, $10 \mathrm{~cm}$ 土壤温度受气温影响也开始迅 速上升, 最后高于较深层土壤温度。不同季节土壤温度日变化特征为: 土壤温度日变幅均为夏季最大, 冬季最 小, 日最高温出现在夏季, 日最低温出现在冬季, 与缑倩倩等 ${ }^{[24]}$ 的研究结果一致。不同季节土壤温度均为火 龙果地 $>$ 荒地 $>$ 花椒地 $>$ 金银花地, 这主要是因为火龙果地植被覆盖率低, 加之人工除草, 导致土壤接收的直接 太阳辐射量较大, 土壤温度较高; 荒地人为干扰少, 杂草丛生, 地表有一定的覆盖度, 土壤透气性较好, 有利于 地表接收太阳辐射; 花椒地的伴生植物多, 增加了地表覆盖度, 且土质较疏松; 而金银花茎叶茂盛, 遮阴效果 好, 高密度的地表覆盖及调落物的存在使土壤受阳光直射的影响小。因此, 金银花地土壤温度明显低于其他 3 种土地类型。校亮等 ${ }^{[9]}$ 发现随着覆被量增加, 土壤温度的波动幅度明显减小。在植被覆盖度高的环境下, 植被对土壤温度的调节作用, 降低了土壤温度, 日变幅也随之减小, 所以植被覆盖度和太阳辐射是土壤温度变 化的重要因素。10 $\mathrm{cm}$ 土壤温度日变幅表现为火龙果地、金银花地大于花椒地、荒地, 火龙果土壤温度日变幅 最大。说明火龙果地与金银花地对土壤温度的调节作用较差, 而花椒地与荒地较优。这主要是因为花椒地和 荒地土壤容重小、总孔隙度高, 有利于土壤呼吸, 加之土壤砂粒和有机碳含量高于火龙果地和金银花地, 砂粒 导热率高,土壤有机碳有利于改善土壤微团聚体结构,改善土壤理化性质,从而增强了土壤导热性能。

土壤温度剖面的变化具有明显的季节差异。夏季 $10 \mathrm{~cm}$ 土壤温度最高, 土层越深,温度越低;秋、冬季 10 $\mathrm{cm}$ 土壤温度最低, 土层越深, 温度越高, 与刘引鸽等 ${ }^{[25]}$ 的研究结果具有一致性。夏季气温较高, 气温对浅层 土壤温度的影响较大, 土壤表面吸收太阳辐射而增温, 并通过热传导向深处传递热量, 土层越深,获得的热量 愈少, 故土壤温度随深度增加而降低; 而秋、冬季气温较低, 地表接收的太阳辐射小于地表长波辐射,地表温度 下降,深层土壤受气温影响较小, 当温度下降到比深层的温度低时, 热量将由深层向地表传输, 但由于从下层 得到的热量不足以抵消地表辐射带来的降温, 因此, 土壤温度随土层加深而逐渐升高。土壤温度垂直变异系 数为冬季最大, 夏季最小, 说明夏季土壤的保温效果较好, 冬季较差。这主要是因为夏季各样地植被覆盖度较 高, 植被对土壤温度的调节作用明显, 而冬季植被覆盖度低,植被调节作用较小,土壤温度的垂直变异明显。

\section{2 环境因子对土壤温度变化的影响}

相关分析表明, 土壤温度与环境因子关系密切。土壤温度日变幅与土壤有机碳、砂粒含量、非毛管孔隙度 均呈极显著正相关,与粉粒含量、容重呈显著负相关。这主要是因为不同土壤质地的通气、肥力和热量条件差 异较大 ${ }^{[26]}$ 。砂粒、粉粒和粘粒对于土壤热扩散性质的贡献不同,砂粒的导热率高于粉粒和粘粒。有机碳是土 壤呼吸的底物, 随着土壤有机碳的累积, 土壤容重、含水量、孔隙度、电导率等土壤理化性质也会发生相应改 善, 从而影响土壤的热容量和导热性能。研究区的峡谷地貌因高原晚期强烈抬升, 河流下切, 周围的洼地形成 岩石裸露的深洼, 植被覆盖较少, 加上洼地沿构造走向发育演化成喀斯特干谷, 形成干热的气候条件, 表现为 冬春温干, 夏秋湿热, 热量资源丰富 ${ }^{[27-28]}$ 。土壤温度与气温和太阳辐射呈显著正相关, 土层越深, 相关性越 弱。与宋长春、王毅勇等 ${ }^{[29]}$ 的研究结果一致。这主要是因为气温和太阳辐射主要通过热传导和热对流的方 式将热量由浅层土壤传递给深层土壤, 随着土层深度的增加, 无论热传导, 还是热对流所携带的能量都逐渐减 少, 所以土层越深, 气温和太阳辐射对土壤温度的影响越小。荒地土壤温度对气温的响应最快, 火龙果地滞后 效应最明显, 这主要是因为荒地受人为干扰较少, 微生物种类丰富, 微生物活动范围达到深层土壤, 土壤有机 碳含量较高, 改善了土壤容重、孔隙度等理化性质, 土壤砂粒含量高, 增强了土壤导热性; 而火龙果地无调落物 的同时长期施用化肥, 加之强烈的人为干扰, 导致土壤板结, 因而具有较大的容重, 土壤紧实, 不利于植物根系 伸展及微生物活动, 导致土壤孔隙度减小, 影响土壤与大气的通透性。加之土壤有机碳含量低, 土壤保水保肥 
能力差, 土壤砂粒含量低, 土壤导热性差, 从而影响了火龙果地对土壤温度的调节及土壤温度响应气温变化的 速度和幅度。

与水分相比,土壤热容量小且热传导率大, 因此干土总是比湿土变冷或变热的要快 ${ }^{[30]}$ 。与其他 3 种土地 类型相比, 火龙果地土壤表层水分含量大, 容重大, 土壤温度的变化比较缓慢。已有研究发现土壤温度与土壤 含水量呈显著负相关 ${ }^{[31-32]}$, 而在其他的一些实验中, 表现为负相关不显著 ${ }^{[33]}$ 。王红梅等 ${ }^{[34]}$ 认为土壤温度和 土壤水分的相关性表现为小采样粒度 $(0.5 \mathrm{~m} \times 0.5 \mathrm{~m}, 1 \mathrm{~m} \times 1 \mathrm{~m})$ 的显著负相关性,而在较大采样粒度 $(2 \mathrm{~m} \times$ $2 \mathrm{~m}, 5 \mathrm{~m} \times 5 \mathrm{~m}$ ) 表现为显著的正相关关系, 表明土壤水热的相关性研究应考虑采样粒度和尺度对实验结果的 影响。本研究通过在不同土层安装土壤水分温度电导率传感器来获取土壤温度和水分数据, 结果表明土壤温 度与土壤含水量呈显著正相关。本研究结果与以往研究存在差异, 可能是因为研究区雨热同期的气候特征, 当大气降水进人土壤后, 土壤水作为运输载体将土壤温度由表层土壤输送到深层土壤, 由于水具有较大的比 热容, 从而增大了土壤的比热容, 对土壤具有一定的增温作用, 因此土壤温度与土壤含水量呈显著正相关。

\section{4 结论}

(1) 喀斯特地区土壤温度日变化特征为:土壤温度日变幅为夏季较大,秋、冬季较小。10 $\mathrm{cm}$ 处土壤温度 日变幅明显大于较深层土壤, 土层越深, 日变幅越小。土壤温度的日变化随着土层加深出现滞后效应。土壤 温度日变幅表现为火龙果地与金银花地明显大于花椒地与荒地。不同季节 $10 \mathrm{~cm}$ 土壤日平均温度均为火龙 果地>荒地>花椒地>金银花地。

(2) 夏季土层越深, 土壤温度越低; 秋、冬季土层越深, 土壤温度越高。花椒地、荒地、金银花地及火龙果 地土壤垂直温度变异系数均为冬季较大,夏季较小。

(3) 土壤温度与容重、孔隙度、土壤质地、有机碳等土壤理化性质相关性显著。与气温、太阳辐射、土壤含 水量均呈显著正相关。花椒地对土壤温度的调节效果较好, 且土壤含水量较高, 土壤持水性较好, 土壤容重 小、孔隙度高。因此, 在喀斯特地区生态恢复的过程中, 种植花椒能在一定程度上改善土壤性质, 提升土壤 肥力。

致谢: 感谢课题组蔡路路等对实验的帮助。

\section{参考文献 (References) :}

[ 1 ] 袁道先. “岩溶作用与碳循环”研究进展. 地球科学进展, 1999, 14(5): 425-432.

[ 2 ] 袁道先. 岩溶与全球变化研究. 地球科学进展, 1995, 10(5): 471-474.

[ 3 ] 翁金桃. 碳酸盐岩在全球碳循环过程中的作用. 地球科学进展, 1995, 10(2)：154-158.

[ 4 ] 欧阳自远. 中国西南喀斯特生态脆弱区的综合治理与开发脱贫. 世界科技研究与发展, 1998, 20(2): 53-56.

[ 5 ] 张慧智, 史学正, 于东升, 王洪杰, 赵永存, 孙维侠, 黄宝荣. 中国土壤温度的空间预测研究. 土壤学报, 2009, 46(1): 1-8.

[ 6 ] 张林. 荒漠草原土壤有机碳向土壤无机碳酸盐转移的定性与定量研究 [D]. 北京: 北京林业大学, 2010.

[ 7 ] Liu M X, Xu X L, Sun A Y, Wang K L, Liu W, Zhang X Y. Is southwestern China experiencing more frequent precipitation extremes? Environmental Research Letters, 2014, 9(6): 064002.

[ 8 ] 王忠媛, 谢江波, 王玉刚, 李彦. 温度对盐土和碱土土壤无机 $\mathrm{CO}_{2}$ 通量的影响. 生态学杂志, 2013, 32(10): 2525-2531.

[ 9 ] 校亮, 熊东红, 张宝军, 张素, 吴汉, 杨丹, 李建查, 史亮涛. 葛藤覆被下干热河谷冲沟沟岸土壤水热变化特征. 生态学报, 2018,38 (2) : 646-656.

[10] Li R, Hou X Q, Jia Z K, Han Q F, Ren X L, Yang B P. Effects on soil temperature, moisture, and maize yield of cultivation with ridge and furrow mulching in the rainfed area of the Loess Plateau, China. Agricultural Water Management, 2013, 116: 101- 109.

[11] 孙建, 刘苗, 李立军, 刘景辉, Acharya S N. 不同耕作方式对内蒙古旱作农田土壤水热状况的影响. 生态学报, 2010, 30(6): 1539-1547.

[12] 陈丽娟, 张新民, 王小军, 成自勇, 单鱼洋. 不同土壤水分处理对膜上灌春小麦土壤温度的影响. 农业工程学报, 2008, 24(4): 9-13.

[13] 王建东, 龚时宏, 于颖多, 梁艳平. 地面灌灌水频率对土壤水与温度及春玉米生长的影响. 水利学报, 2008, 39(4): 500-505.

[14] 唐振兴, 何志斌, 刘鹄. 祁连山中段林草交错带土壤水热特征及其对气象要素的响应. 生态学报, 2012, 32(4) : $1056-1065$. 
[15] 牛望, 刘贤德, 吕一河, 金铭, 王顺利, 胡健. 祁连山大野口流域土壤水热垂直分层变化特征分析. 干旱区资源与环境, 2016, 30(6)： $141-146$.

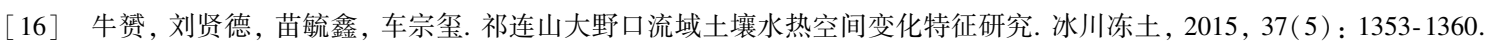

[17] Hu Q, Feng S. A daily soil temperature dataset and soil temperature climatology of the contiguous United States. Journal of Applied Meteorology, 2003, 42(8): 1139-1156.

[18] 吴克华, 熊康宁, 李坡, 龙明忠, 曲明昕. 不同等级石漠化综合治理的小气候效应一一贵州省花江峡谷为例. 地球与环境, 2009, 37 (4) : 411-418

[19] 张邦琨, 曾信波. 喀斯特森林的土壤温度变化规律. 土壤, 1996, 28(1)：46-48.

[20] 熊康宁, 陈永毕, 陈吘, 兰安军, 隋喆. 点石成金一一贵州石漠化治理技术与模式. 贵阳: 贵州科技出版社, 2011: 12-12.

[21] 陈继康, 李素娟, 张宇, 陈阜, 张海林. 不同耕作方式麦田土壤温度及其对气温的响应特征一土壤温度日变化及其对气温的响应. 中 国农业科学, 2009, 42(7): 2592-2600.

[22] 孙贯芳, 杜斌, 屈忠义, 李昌见, 张智丽, 李锡环. 不同灌溉模式下土壤温度的变化及对气温的响应特征. 土壤, 2016, 48(3): 581-587.

[23] 刘士玲, 杨保国, 卢立华, 张培, 雷丽群, 何远, 郑路. 广西大青山土壤水热特征及其对气象要素的响应. 中南林业科技大学学报, 2018, $38(11): 46-52$.

[24］缑倩倩, 李乔乔, 屈建军, 王国华. 荒漠-绿洲过渡带土壤温度变化分析. 干旱区研究, 2019，36(4)：809-815.

[25] 刘引鸽, 周欢欢, 胡浩楠, 方建刚, 龙颜. 西安地区土壤浅层温度变化特征. 干旱区资源与环境, 2019, 33(8): 153-159.

[26] 王萌萌, 何新林, 吕廷波, 曹玉斌, 王东旺. 土壤质地对机采棉土壤水热状况及生长发育影响研究. 灌溉排水学报, 2017, 36(10)： 28-33.

[27] 容丽, 王世杰, 杜雪莲. 喀斯特低热河谷石漠化区环境梯度的小气候效应一以贵州花江峡谷区小流域为例. 生态学杂志, 2006,25 (9) : 1038- 1043 .

[28] 高贵龙, 邓自民, 熊康宁, 苏孝良. 喀斯特的呼唤与希望: 贵州喀斯特生态环境建设与可持续发展. 贵阳: 贵州科技出版社, 2003.

[29] 宋长春, 王毅勇. 湿地生态系统土壤温度对气温的响应特征及对 $\mathrm{CO}_{2}$ 排放的影响. 应用生态学报, 2006, 17(4): 625-629.

[30] Azooz R H, Lowery B, Daniel T C, Arshad M A. Impact of tillage and residue management on soil heat flux. Agricultural and Forest Meteorology, 1997, 84(3/4): 207-222.

[31] 车宗䇛, 李进军, 汪有奎, 丁国民, 李世霞, 邸华, 车宗彩, 潘欣, 毛志明, 郭朝霞. 祁连山西段草地土壤温度、水分变化特征. 生态学报, 2018, 38(1): 105-111.

[32] Bond-Lamberty B, Brown K M, Goranson C, Gower S T. Spatial dynamics of soil moisture and temperature in a black spruce boreal chronosequence. Canadian Journal of Forest Research, 2006, 36(11): 2794-2802.

[33] Bond-Lamberty B, Wang C K, Gower S T. Spatiotemporal measurement and modeling of stand-level boreal forest soil temperatures. Agricultural and Forest Meteorology, 2005, 131(1/2): 27-40.

[34] 王红梅, 王掠, 米佳, 叶上游, 赵娜. 北方农牧交错带沽源农田-草地界面土壤水热空间特征. 生态学报, 2009, 29(12)：6589-6599. 